\title{
Low-cost farmed shrimp shells could remove arsenic from solutions kinetically
}

\author{
Chia-Pin Chio ${ }^{\mathrm{a}}$, Ming-Chao Lin ${ }^{\mathrm{b}}$, Chung-Min Liao ${ }^{\mathrm{a}, *}$ \\ a Department of Bioenvironmental Systems Engineering, National Taiwan University, Taipei 10617, Taiwan, ROC \\ ${ }^{\mathrm{b}}$ Department of Natural Biotechnology, Nanhua University, Chiayi 622, Taiwan, ROC
}

\section{A R T I C L E I N F O}

\section{Article history:}

Received 17 January 2009

Received in revised form 13 June 2009

Accepted 16 June 2009

Available online 24 June 2009

\section{Keywords:}

Shrimp shell

Arsenic

Adsorption isotherm

Adsorption kinetics

Low cost

\begin{abstract}
A B S T R A C T
The purpose of this study was to explore the ability of shrimp shell to remove arsenic (As) from aqueous solutions by experimental and modeling analyses. The shells of two species of farmed shrimp, black tiger shrimp (Penaeus monodon) and white shrimp (Litopenaeus vannamei), were chosen to be the sorbents. The results indicate that sorption capacities of black tiger shrimp and white shrimp shells were estimated to be $8.1 \times 10^{-3}$ to $5.0 \times 10^{-1}$ and $7.8 \times 10^{-3}$ to $2.4 \times 10^{-1} \mathrm{mg} \mathrm{g}^{-1}$, respectively. Results show that the sorption capacities of the shell of black tiger shrimp did not significantly differ from those of white shrimp by through analysis of variance ANOVA $(F=1.50, n=18, P>0.05)$. This study found that Langmuir and Fruendlich isotherm models described the adsorption processes well $\left(r^{2}>0.90\right)$. The Langmuir-based maximum adsorption capacity was estimated to be $0.125-0.126 \mathrm{mg} \mathrm{g}^{-1}$, whereas the Fruendlich-based adsorption capacities ranged from 0.105 to $0.124 \mathrm{mg} \mathrm{g}^{-1}$. Model analysis based on pseudo-second-order kinetics reveals that sorption capacity of shrimp shell increases with the initial As concentration and retention time in water. Based on isotherm and kinetic analyses, the sorption capacity of shell of black tiger shrimp is slight higher but insignificant than that of shell of white shrimp for As removal from solution. A combination of experiments and modeling suggests that shrimp shell, as a waste material, could be utilized potentially for the removal of As from an aqueous medium. Although the As-removal capacity of shrimp shell was lower than those of natural and chemical sorbents, using shrimp shells as sorbents is less expensive and could increase the additional benefit of shrimp products.
\end{abstract}

(c) 2009 Elsevier B.V. All rights reserved.

\section{Introduction}

World Health Organization [1] considered arsenic (As) is the top environmental chemical of concern. Arsenic also ranks first on the Agency for Toxic Substances and Disease Registry list of priority pollutants in the environment (http://www.atsdr.cdc.gov/cercla/05list.html). Several epidemiological studies confirm that there is an increased risk of cancer in case of exposure to As [2]. The main reason that people exposed to As is because they come in contact with As containing water, especially groundwater. Arsenic enters the food chain via aquatic organisms, which is also a risk to human health, if these organisms are consumed by humans [3-6]. Systemic and chronic exposure to As is known to lead to serious disorders, e.g., vascular diseases, such as blackfoot disease (BFD) and hypertension, irritations of the skin and mucous membranes as well as dermatitis, keratosis, and melanosis [7]. Inorganic As is a human carcinogen, and ingestion of inorganic arsenic increases the risk of developing cancer of the bladder, liver, kidney, and skin [8]. The clinical manifestations of chronic

\footnotetext{
* Corresponding author. Tel.: +88622363 4512; fax: +88622362 6433 .

E-mail addresses: cmliao@ntu.edu.tw, cmliao@ccms.ntu.edu.tw(C.-M. Liao).
}

arsenic are referred to as arsenicosis. At present, there is no effective therapy for arsenicosis, and consequently, treatment involves reducing As exposure and providing specific drugs for recovery and/or averting disease progression.

There are several kinds of techniques to remove As from contaminated water; for instance, coagulation, ultrafiltration, ion exchange, lime softening, adsorption on iron oxides or activated alumina, and reverse osmosis [9-14]. These methods, however, all have important disadvantages because they are expensive and there is a risk for the environment because of deposited rest products such as poisonous sludge. Mohan and Pittman [11] reviewed the As removal techniques from water/wastewater using natural/commercial adsorbents. Commercial adsorbents, such as activated carbons, may have good adsorption capacities for some heavy metals, yet they are expensive. The adsorption capacities for activated carbons strongly depend on their intrinsic properties (e.g., specific surface area), sorbent chemical properties, temperature, $\mathrm{pH}$, ionic strength, and so on [11].

Consequently, there is growing interest in using low-cost materials to remove As from water [11,15]. Arsenic can be adsorbed by different natural materials, such as aquifer, bentonite, bone char, clay, goethite, kaolinite, macrofungus, montmorillonite, oat hulls, sand, sorghum, and spodic materials [10-14,16-20]. Among 
the natural sorbents, chitosan and chitin have the higher sorption capacities for As [11,21]. Chitosan is difficult to be dissolved at low $\mathrm{pH}$ values. It also poses problems of agglomeration and it can form gel in aqueous solutions. Chitosan can be obtained from chitin by a deacetylation process with a strong alkaline solution. Fungi, algae, molluscs, insects, and crustaceans all have chitin as their main component [11,22-24]. Chitin is recognized as an excellent sorbent; the process of producing chitin however, requires large amounts of acid and alkaline. Therefore, other kinds of techniques have to be developed for As removal. Among potential materials, the low-cost fresh shrimp shells can be one of the choices [11,25,26].

The aquaculture of shrimp is a promising business in Taiwan. Taiwan has more than 9000 ha of shrimp cultivating ponds with a total amount of supply and marketing of around $9000 \mathrm{tyr}^{-1}$ [27]. Shrimp consumption generates a large amount of shells. These shells are still considered as solid offal, according to the stipulation of the Environmental Protection Administration in Taiwan. Normally these shrimp shells are just thrown aside wantonly and cause pollution. In this study, we attempted to utilize shrimp shell as adsorbing material to remove As from aqueous solution.

The objective of this study was to evaluate the As adsorption capacities for shrimp shells of two important cultured species of farmed shrimp, black tiger shrimp (Penaeus monodon) and white shrimp (Litopenaeus vannamei), in Taiwan based on experimental and kinetic modeling assessments.

\section{Materials and methods}

\subsection{Experiment}

Black tiger shrimp (BTS) and white shrimp (WS) were obtained from fish markets in Chiayi City, Taiwan, and placed on ice during transfer to the laboratory. Two hundred and seventy individuals from each species, in total 540 shrimps, were selected. The first shell from the abdominal segment of the shrimp was removed from its body and collected for laboratory exposure experiments. The shells were cleaned, rinsed and then soaked in $1 \% \mathrm{NaOH}$ at room temperature overnight to remove the bulk of the protein. After being rinsed with distilled water, the shells were dried in a convection oven (DO45, DENG YNG, Taiwan) at $40^{\circ} \mathrm{C}$ for 3 days. The level of chitin in the shell was analyzed following the method of Juang et al. [28]. The chitin was obtained by immersing the shell in 5 wt.\% $\mathrm{NaOH}$ for $18 \mathrm{~h}$ and later in $5 \mathrm{wt} . \% \mathrm{HCl}$ (with a weight ratio of $1: 10$ for shell to solution) for $18 \mathrm{~h}$.

To determine the sorption capacity of the shrimp shell, adsorption assays were conducted in the laboratory. Since the sorption capacities of black tiger shrimp shell and white shrimp shells might be relatively low, hence we needed to increase the As concentrations in solution to make the As in shrimp shell detectable. The sorption capacity was examined by exposing the shells to As concentrations of $1,2,5,10,20,40,60,80$, and $100 \mathrm{mg} \mathrm{L}^{-1}$ for special design mentioned above. To prepare the concentration of As in water, arsenite $\left(\mathrm{Na}_{3} \mathrm{AsO}_{3}\right)$ was dissolved in distilled water. An amount of 270 dried shells from the same species was separated evenly into 10 flasks, each with a volume of $500 \mathrm{ml}$; thus, every flask contained 27 pieces of shells. One by one the flasks were filled with $400 \mathrm{~mL}$ As solutions in the different concentrations as mentioned above. Three pieces of shells were taken out from each flask at the 0 , 3rd, 6th, 9th, 12th, 24th, 48th, and 96th h and kept at $-20^{\circ} \mathrm{C}$ before they were analyzed. Water samples were taken every $12 \mathrm{~h}$ from each flask, acidified by adding $5 \mathrm{~mL} 1 \mathrm{~N} \mathrm{HNO}_{3}$ and stored for analysis of As concentration. The $\mathrm{pH}$ values of solutions under various As concentrations were measured. Immediately after sampling, the water in the flasks was renewed to maintain the As concentration. The experiment was repeated twice.
For analysis of total As, shell and water samples were sent to the Super Micro Mass Research and Technology Center, Cheng Shiu University, Kaohsiung, Taiwan. The shells were dehydrated in a dryer $\left(40^{\circ} \mathrm{C}\right)$ for $96 \mathrm{~h}$ and grounded into powder. Aliquots of dry shell powder weighing $0.5 \mathrm{~g}$ were placed into a $250 \mathrm{~mL}$ beaker. Nitric acid $(65 \%, 10 \mathrm{~mL})$ was added and then covered with a glass for an overnight digestion.

The beaker was heated with a water bath at $70-80^{\circ} \mathrm{C}$ for $2-4 \mathrm{~h}$ to reduce the total volume to $1-2 \mathrm{~mL}$. The solution in the beaker was transferred to a $50 \mathrm{~mL}$ volumetric flask. The rinsed solution $(5 \mathrm{~mL}$ of $0.01 \mathrm{~N}$ of $\mathrm{HNO}_{3}$ ) for the watch glass was also added to the flask. The flask was then filled with $0.01 \mathrm{~N}$ of $\mathrm{HNO}_{3}$ to make a $50 \mathrm{~mL}$ of final solution. After filtration, this $50 \mathrm{~mL}$ solution was transferred to test tubes for As analysis.

Arsenic analysis was carried out by using an Agilent 7500a ICP-MS. Analytical quality control was achieved by digesting and analyzing identical amounts of rehydrated $\left(90 \% \mathrm{H}_{2} \mathrm{O}\right)$ standard reference materials (DORM-2, Dogfish Liver-2-organic matrix, NRCCNRC, Canada). Recovery rates ranged from $95 \%$ to $97 \%$.

\subsection{Data analysis}

The amount of pollutant adsorbed by the sorbent is equal to the amount of pollutant reduced in water:

$$
Q=\frac{C_{\mathrm{s}}}{1000 \times M},
$$

where $Q$ is sorption capacity $\left(\mathrm{mmol}^{-1}\right), M$ is the molecular weight of pollutant $\left(\mathrm{g} \mathrm{mol}^{-1}\right)$, and $C_{\mathrm{s}}=\left(n_{0}-n_{1}\right) / \mathrm{W}$ is the saturated concentration of sorbent $\left(\mu \mathrm{gg}^{-1}\right)$ in which $n_{0}$ and $n_{1}$ are the original and residual weights of pollutant in water, respectively $(\mathrm{mg})$, and $W$ is the weight of sorbent ( $\mathrm{g}$ ). Eq. (1) is derived based on An et al. [24] by calculating directly from metal mass balance relationships, indicating removed As amounts per unit sorbent dry weight as:

$Q=\frac{\left(C_{0}-C_{1}\right) V}{1000 \times W}$,

where $C_{0}$ and $C_{1}$ are the original and residual concentrations of pollutant in water, respectively $\left(\mathrm{mmol} \mathrm{g}^{-1}\right)$ and $V$ is the volume of metal solution (L). For making the unit for sorption capacity consistent throughout this study, the following descriptions of sorption capacity $(Q)$ were denoted by $\mathrm{mg} \mathrm{g}^{-1}$.

Experimental isotherms are useful for describing adsorption capacity to facilitate evaluation of the feasibility of the process for a given application, for selection of the most appropriate sorbent, and for preliminary determination of sorbent dosage requirements. The isotherm plays an important role in the predictive modeling procedure for analysis and design of sorption systems. The Langmuir and Fruendlich isotherms are most frequently used to represent the data of sorption from solution. The Langmuir model $[10,13,14,20,29,30]$ represents one of the first theoretical treatments of nonlinear sorption and suggests that uptake occurs on a homogeneous surface by monolayer sorption without interaction between adsorbed molecules. The Langmuir model assumes uniform energies of adsorption onto the surface and no transmigration of the sorbent. The linear Langmuir adsorption model was applied to the sorption equilibria at different adsorption doses to establish the maximum sorption capacity:

$\frac{1}{q_{e}}=\frac{1}{Q_{\mathrm{L}}}+\frac{1}{K_{\mathrm{L}} \mathrm{Q}_{\mathrm{L}} C_{e}}$,

where $q_{e}$ is the isotherm related As uptake per mass of adsorbent $\left(\mathrm{mg} \mathrm{g}^{-1}\right), C_{e}$ is the sorbent concentration at equilibrium $\left(\mathrm{mg} \mathrm{L}^{-1}\right)$, $\mathrm{Q}_{\mathrm{L}}\left(\mathrm{mg} \mathrm{g}^{-1}\right)$ and $K_{\mathrm{L}}\left(\mathrm{L}^{-1} \mathrm{mg}\right)$ are the Langmuir constants related to maximum adsorption capacity and the binding energy of the sorption system, respectively. 


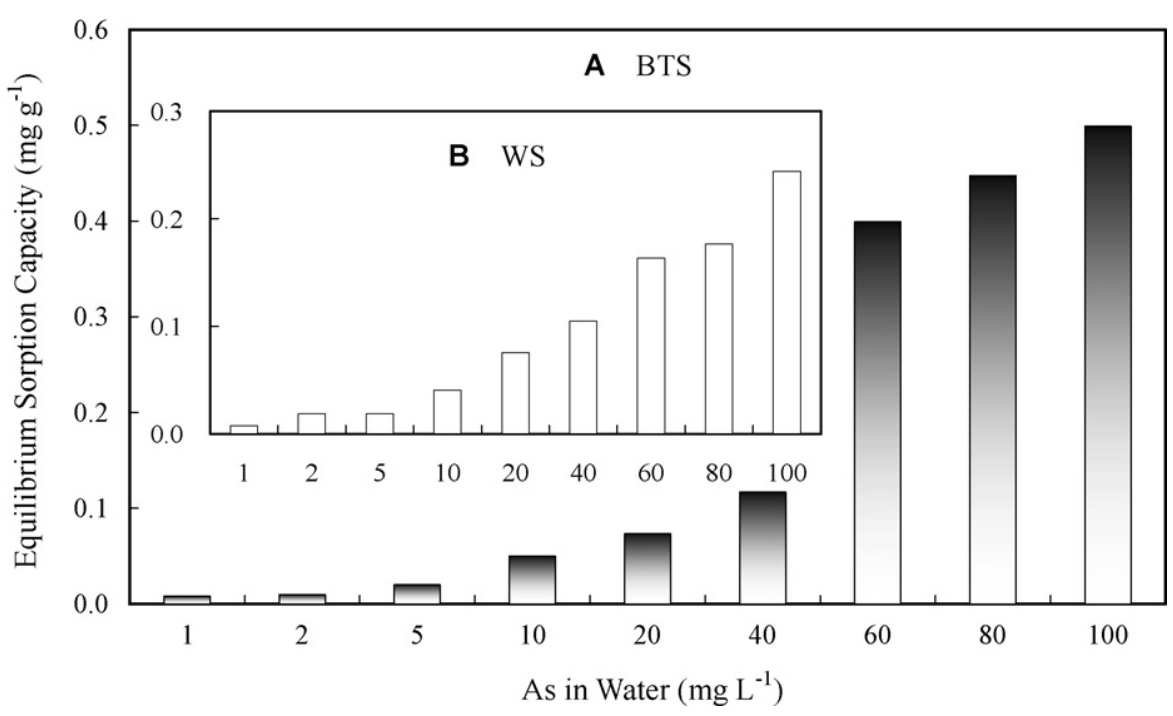

Fig. 1. The equilibrium sorption capacities of the shells of (A) black tiger shrimp (BTS) and (B) white shrimp (WS) under various As concentrations in water.

The Fruendlich isotherm $[10,13,14,20,29]$ is a nonlinear sorption model in that the model proposes a monolayer sorption with a heterogeneous energetic distribution of active sites accompanied by interactions between adsorbed molecules. A logarithmic linear Fruendlich model is applied to sorption equilibria at different sorbent doses:

$\log q_{e}=\log K_{\mathrm{F}}+\frac{1}{n} \log C_{e}$,

where $K_{\mathrm{F}}$ represents the adsorption capacity $\left(\mathrm{mg} \mathrm{g}^{-1}\right)$ and $n$ denotes the adsorption intensity. The values of $1 / n$ varies between 0.1 and 1.0 indicate the favorable adsorption of As.

A widely used pseudo-second-order kinetic model was employed to analyze the kinetics of the sorption system [28-31]:

$\frac{t}{q}=\frac{1}{k q_{e}^{2}}+\frac{t}{q_{e}}$,

where $t$ is the contact time (h), $q$ is the quantity of sorbent adsorbed

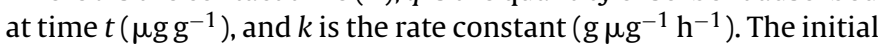
sorption rate can be obtained as $q / t$ approaches zero:

$h_{0}=k q_{e}^{2}$,

where $h_{0}$ is the initial sorption rate $\left(\mu \mathrm{gg}^{-1} \mathrm{~h}^{-1}\right)$.

The linear option of Statistica software (StatSoft, Tulsa, OK) was used to perform all curve fittings. Statistica software was also used to calculate the coefficient of determination $\left(r^{2}\right)$ and statistical analyses (analysis of variance and Students $t$-test). Statistical significance was determined at $P<0.05$. For performing three-dimension plot, the TableCurve 3D packages (Version 4.0, AISN Software Inc., Mapleton, OR, USA) was employed.

\section{Results and discussion}

\subsection{Characteristics and sorption capacity}

The physical and chemical features in the structure of the shrimp shells of these two species, black tiger shrimp and white shrimp, used in this study were also described. The length, wet weight, and dry weight of black tiger shrimp were $15.49 \pm 0.55 \mathrm{~cm}, 21.51 \pm 1.64$, and $4.89 \pm 0.42 \mathrm{~g}$, respectively, while those of white shrimp were $14.61 \pm 0.36 \mathrm{~cm}, 17.93 \pm 1.58$, and $4.34 \pm 0.39 \mathrm{~g}$, respectively. The specific surface area of shells of black tiger shrimp and white shrimp were 0.011 and $0.023 \mathrm{~m}^{2} \mathrm{~g}^{-1}$, respectively. The shrimp shells were cleaned, rinsed and then soaked in $1 \% \mathrm{NaOH}$ to remove the bulk of the protein on the surface of the shells

The sorption capacities of the shells of BTS and WS ranged from $1.08 \times 10^{-4}$ to $6.66 \times 10^{-3} \mathrm{mmolg}^{-1}$ (i.e. $8.1 \times 10^{-3}$ to $5.0 \times 10^{-1} \mathrm{mg} \mathrm{g}^{-1}$ ) and $1.04 \times 10^{-4}$ to $3.26 \times 10^{-3} \mathrm{mmolg}^{-1}$ (i.e. $7.8 \times 10^{-3}$ to $2.4 \times 10^{-1} \mathrm{mg} \mathrm{g}^{-1}$ ), respectively (Fig. $1 \mathrm{~A}$ and $\mathrm{B}$ ). The resulting data also showed that there were significantly association between equilibrium sorption capacities and the concentrations of As-contained solution for both of the shells of BTS and WS. According to the analysis of variance (ANOVA), results showed that the sorption capacities of the shells of BTS and WS had no significant difference $(F=1.50, n=18, P>0.05)$, indicating that the two kinds of shrimp shell had a similar capacity to adsorb As from the aqueous solution.

Dambies et al. [32] noted that the sorption capacities of activated carbon, activated mineral surfaces, alumina, bauxite, chitin, coral limestone and silica were lower than $0.1-0.2 \mathrm{mmolg}^{-1}$ (i.e. $7.5-15 \mathrm{mg} \mathrm{g}^{-1}$ ). Ghimire et al. [33] pointed out that the sorption capacities of orange waste and cellulose for removing As were estimated to be 1.21 and $0.96 \mathrm{mmol} \mathrm{g}^{-1}$ (i.e. 90.6 and $71.9 \mathrm{mg} \mathrm{g}^{-1}$ ), respectively. The natural materials will be influenced by $\mathrm{pH}$ values. The chemical materials will not be influenced by $\mathrm{pH}$ values, but they cause a side effect bearing As-sludge. Moreover, these chemicals remain expensive. The sorption capacity of shrimp shell is lower than those of natural and chemical sorbents, but the shrimp shell will not have the same problems mentioned above [24]. The $\mathrm{pH}$ values of the solutions in this study remained between 6.03 and 7.02. Dambies et al. [32] have shown that the sorption capacity of raw chitosan beads for As(III) removal remained constant, independently of the $\mathrm{pH}$. The influence of $\mathrm{pH}$ change on the sorption capacity of shrimp shell in this study can be neglected. The shrimp shell therefore could be potentially used as sorbent of As in aqueous medium. Thus, the shell of shrimp, as well as other shellfish, crabs, and krill creates, should not be considered as waste materials, but better be recycled and used for removal of As [24]. It is cheap and useful to prevent pollution [34]. Therefore, using these shell wastes could also increase the additional benefits of fishery and aquaculture products.

\subsection{Adsorption isotherm}

The Langmuir isotherm simulation for As sorption by shells of BTS and WS were depicted in Fig. 2A and B, whereas the fitted Fru- 

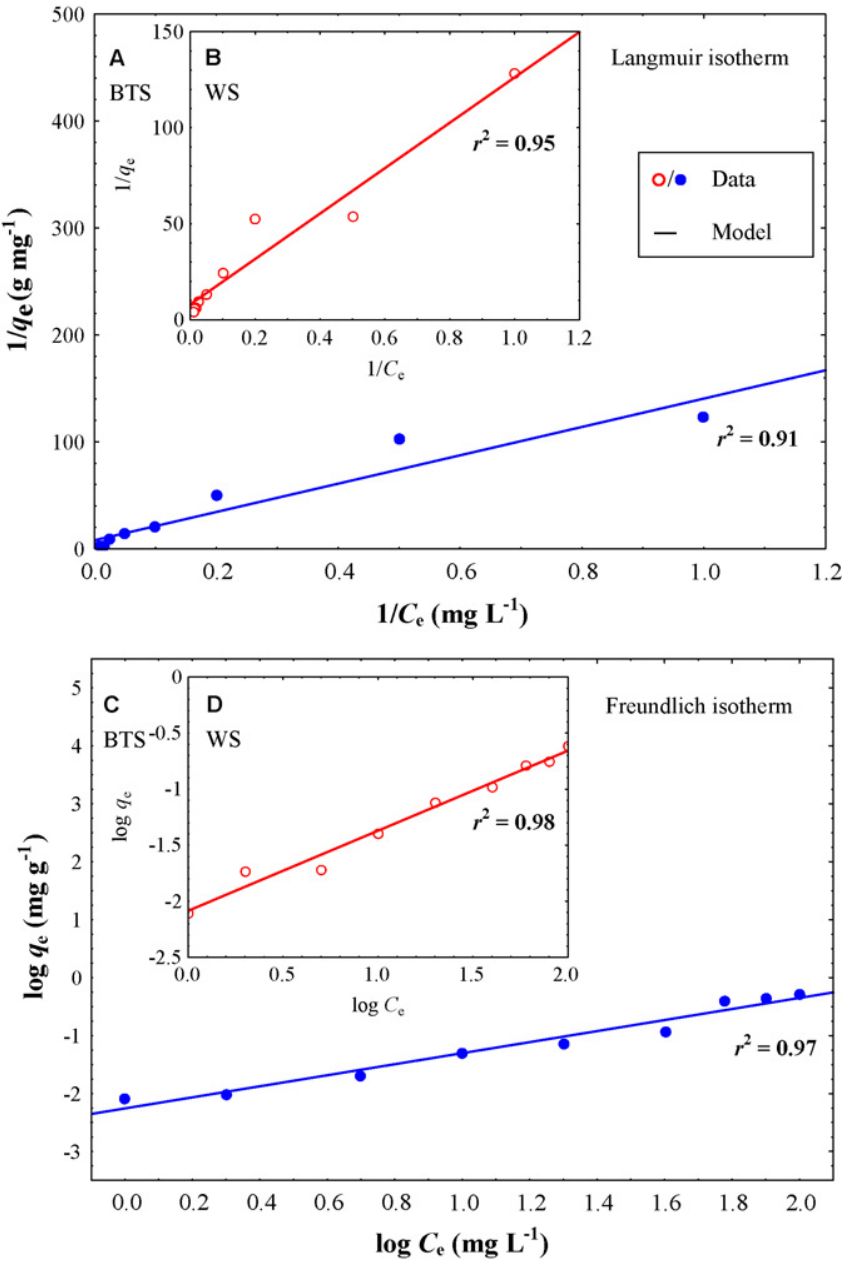

Fig. 2. Langmuir and Fruendlich isotherm simulations for As sorption by shells of (A and C) black tiger shrimp (BTS) and (B and D) white shrimp (WS).

endlich isotherm model for those were shown in Fig. 2C and D. All of them (Fig. 2A-D) displayed good linear correlations between inverse and $\log$ transformed $q_{e}$ (As uptake per mass of adsorbent) and the corresponding transformed $C_{e}$ (sorbent concentration at equilibrium) for shells of BTS and WS. The fitted parameters were summarized in Table 1 . Results showed that high correlations $\left(r^{2}=0.91-0.98\right)$ were found for two type isotherms fitted to the experimental data of two As-shrimp shell systems.

In Langmuir isotherm analysis, results showed that there were no significant differences on maximum adsorption capacity $\left(Q_{\mathrm{L}}\right.$ were estimated to be 0.126 and $0.125 \mathrm{mg} \mathrm{g}^{-1}$ for BTS and WS, respectively) between selected two shells. Only the regression slope $\left(1 / K_{\mathrm{L}} \mathrm{Q}_{\mathrm{L}}\right)$ for BTS $\left(1 /(0.06 \times 0.126)=132 \mathrm{~g}^{-1} \mathrm{mg}^{-2}\right)$ is relatively higher than that for WS $\left(1 /(0.068 \times 0.125)=118 \mathrm{~g}^{-1} \mathrm{mg}^{-2}\right)$. Similarly, the regression slope $(1 / n)$ for BTS $(1 / 1.05=0.95)$ is relatively higher than that for WS $(1 / 1.40=0.71)$ in the Fruendlich isotherm

\section{Table 1}

Modeling of As sorption isotherms by using Langmuir and Fruendlich equations for black tiger shrimp and white shrimp shells.

\begin{tabular}{llll}
\hline \multicolumn{2}{l}{ Isotherm model } & Black tiger shrimp & White shrimp \\
\hline Langmuir & $K_{\mathrm{L}}\left(\mathrm{L} \mathrm{mg}^{-1}\right)$ & 0.060 & 0.068 \\
& $\mathrm{Q}_{\mathrm{I}}\left(\mathrm{mg} \mathrm{g}^{-1}\right)$ & 0.126 & 0.125 \\
& $r^{2}$ & 0.91 & 0.95 \\
Fruendlich & $K_{\mathrm{F}}\left(\mathrm{mg} \mathrm{g}^{-1}\right)$ & 0.105 & 0.124 \\
& $n$ & 1.05 & 1.40 \\
& $r^{2}$ & 0.97 & 0.98 \\
\hline
\end{tabular}

analysis, although the interceptions $\left(\log K_{\mathrm{F}}\right)$ showed an inverse trend $\left(-2.25\right.$ and $-2.09 \mathrm{mg} \mathrm{g}^{-1}$ for BTS and WS, respectively).

Although many isotherm models, e.g., Langmuir, Fruendlich, Redlich-Peterson (R-P), and Dubini-Radushkevich (D-R), had been proposed [29], we only selected the first two isotherms based on the limitations in our data and simplified reasons. These first two isotherm models of Langmuir and Fruendlich were represented the nonlinear sorption in homogeneous surface and in heterogeneous energetic distribution of active sites by monolayer sorption, respectively. The R-P isotherm is the other form of Langmuir isotherm, that is, the Langmuir isotherm is known as a specific (simplest) form of the R-P isotherm. However, the D-R isotherm is not suitable be applied in our study due to the data limitation.

Recently, A. niger [13], chitson bead [32], oat hull [20], and sorghum biomass [10] had also been used as sorbent for As removal (Table 2). Both of Langmuir and Fruendlich isotherms described well for As adsorption, most of $r^{2}$ were greater than 0.95 . For arsenate $(\mathrm{As}(\mathrm{V}))$ adsorption by Langmuir isotherm, the molybdate coagulated chitosan beads (MCCB) and molybdate impregnated chitosan beads (MICB) [32] were performed the higher maximum adsorption capacity $\left(Q_{\mathrm{L}}\right)$ sorbent compared with the other three materials (oat hulls [20], A. niger [13], and sorghum biomass [10]). In our study, contrary to the other studies, we did not use the beads and particles but the whole piece of shrimp shell as sorbent. The specific surface area $\left(\mathrm{m}^{2} \mathrm{~g}^{-1}\right)$ of shell was calculated dividing the
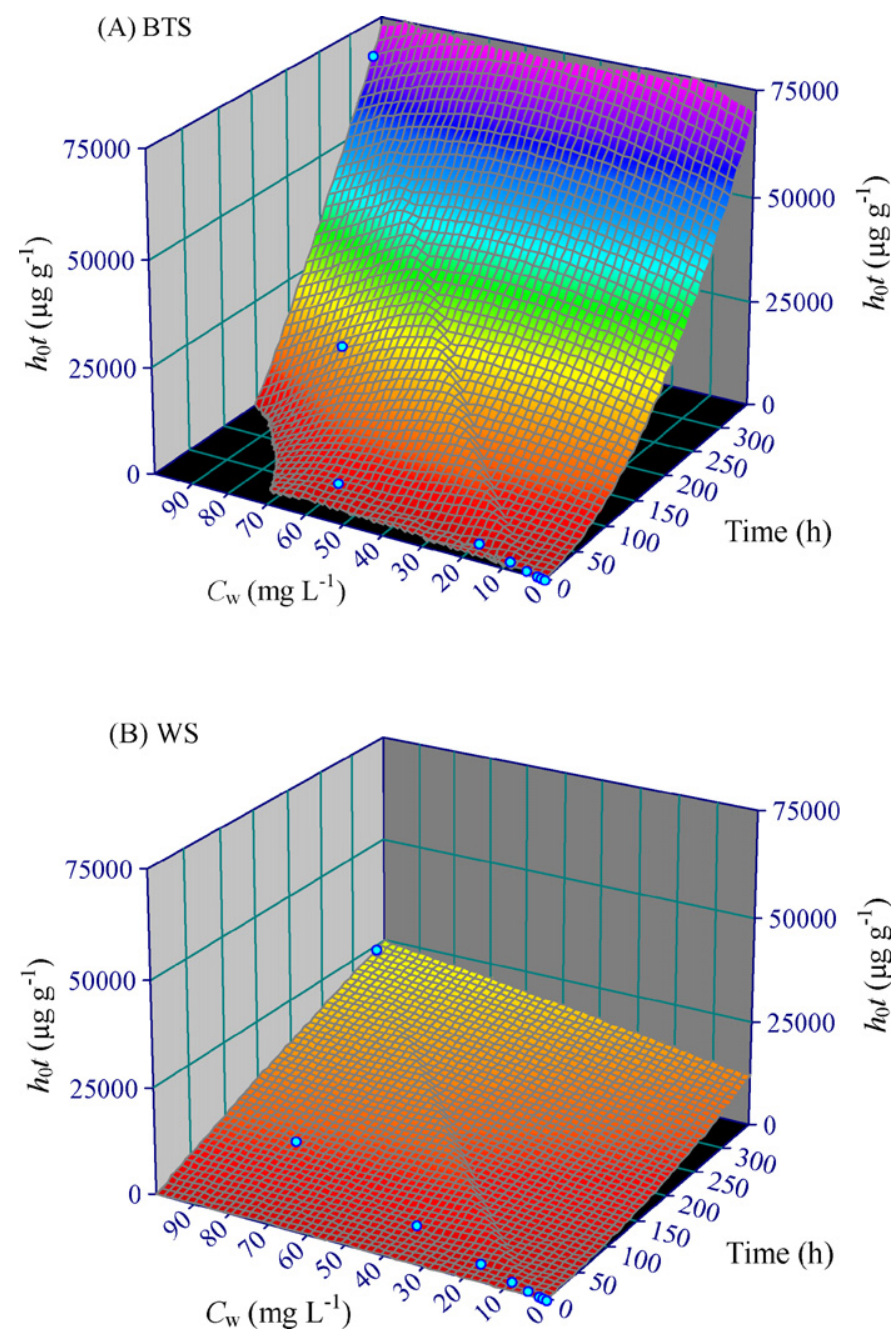

Fig. 3. Response surface representations of the maximum As sorption capacities at various retention time and As initial concentrations in water by shells of $(A)$ black tiger shrimp (BTS) and (B) white shrimp (WS). 
Table 2

Comparisons of different sorbents applied onto As speciation sorption.

\begin{tabular}{|c|c|c|c|c|c|}
\hline Sorbent $^{\mathrm{a}}$ & As speciation & $K_{\mathrm{L}}\left(\mathrm{L} \mathrm{mg}^{-1}\right)$ & $Q_{\mathrm{L}}\left(\mathrm{mg} \mathrm{g}^{-1}\right)$ & $r^{2}$ & Reference \\
\hline \multicolumn{6}{|c|}{ Langmuir isotherm model } \\
\hline MCCB & $\mathrm{As}(\mathrm{V})$ & $0.12 \pm 0.05^{b}$ & $211.2 \pm 16.4$ & $\mathrm{NA}^{\mathrm{c}}$ & [32] \\
\hline MICB & $\mathrm{As}(\mathrm{V})$ & $0.11 \pm 0.02$ & $197.6 \pm 8.8$ & NA & [32] \\
\hline Oat hulls & $\mathrm{As}(\mathrm{V})$ & $39.6-44.2^{\mathrm{d}}$ & 1.57-3.09 & $0.95-0.99$ & [20] \\
\hline A. niger & $\mathrm{As}(\mathrm{V})$ & 0.059 & 0.060 & 0.95 & [13] \\
\hline NISB/ISB & $\mathrm{As}(\mathrm{V})$ & $0.26-0.55$ & 0.0029-0.0036 & $0.98-0.99$ & [10] \\
\hline MCCB & $\operatorname{As}(\mathrm{III})$ & $0.04 \pm 0.02$ & $69.2 \pm 6.6$ & NA & [32] \\
\hline BTS shells & As(III) & 0.060 & 0.126 & 0.91 & This study \\
\hline WS shells & As(III) & 0.068 & 0.125 & 0.95 & This study \\
\hline Sorbent & & $K_{\mathrm{F}}\left(\mathrm{mg} \mathrm{g}^{-1}\right)$ & $n$ & $r^{2}$ & \\
\hline \multicolumn{6}{|c|}{ Fruendlich isotherm model } \\
\hline Oat hulls & $\mathrm{As}(\mathrm{V})$ & $0.39-0.49$ & $2.48-5.10$ & $0.84-0.94$ & [20] \\
\hline NISB/ISB & $\operatorname{As}(V)$ & $0.73-1.02$ & $1.39-1.41$ & 0.99 & [10] \\
\hline BTS shells & $\mathrm{As}(\mathrm{III})$ & 0.105 & 1.05 & 0.97 & This study \\
\hline WS shells & $\mathrm{As}(\mathrm{III})$ & 0.124 & 1.40 & 0.98 & This study \\
\hline
\end{tabular}

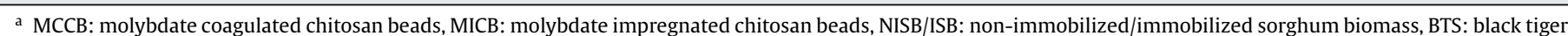
shrimp, and WS: white shrimp.

b Mean \pm SD.

c Not available.

d Min-max.

surface area $\left(\mathrm{m}^{2}\right)$ by the dry weight $(\mathrm{g})$. The specific surface areas of raw shrimp shell were $0.011-0.023 \mathrm{~m}^{2} \mathrm{~g}^{-1}$, while those of the crab shell particles and the chitosan beads were 13.35 and $12.50 \mathrm{~m}^{2} \mathrm{~g}^{-1}$, respectively $[28,32]$. The difference in specific surface area between shrimp shell and crab shell particles, as well as-shrimp shell and chitosan beads, is rather large (more than 500 times). That is the reason we concluded that the difference in specific surface area could be the main reason for the significant difference in sorption capacity between shrimp shell and the other two materials mentioned above. But, it does not mean that the adsorption capacity of shrimp shell is mainly influenced by the specific surface area.

\subsection{Kinetic studies}

The corresponding values of $q_{e}, k$, and $h_{0}$ against $C_{\mathrm{w}}$ were regressed to obtain expressions for these regression values in terms of the initial As concentration with high correlation coefficients (Table 3). The pertinent parameters of pseudo-second-order sorp- tion equation used to model the shells of BTS and WS, including the fitted slope (i.e. $1 / q_{e}$ ) and interception (i.e. $1 / k q_{e}^{2}$ ), had been estimated (Table 3 ). The fitted $r^{2}$ for shells of BTS and WS ranged from 0.871 to 0.999 and $0.932-0.999$, respectively. Results indicated that the fitted slope and interception for both shells of BTS and WS showed a decrease pattern association with increase of the initial As concentration $\left(C_{\mathrm{w}}\right)$ in aqueous solution. However, the estimated sorption capacity $\left(q_{e}\right)$ and initial sorption rate $\left(h_{0}\right)$ showed a similar trend with increase of the initial As concentration $\left(C_{\mathrm{w}}\right)$ in aqueous solution.

The results also showed that the maximum sorption for BTS $\left(h_{0} t=75,000 \mu \mathrm{gg}^{-1}\right)$ was approximately 3 times higher than that for WS $\left(25,000 \mu \mathrm{gg}^{-1}\right)$ (Fig. 3 ) because of the maximum quantity of sorbent for BTS in equilibrium state $\left(q_{e}=569 \mu \mathrm{g} \mathrm{g}^{-1}\right)$ is approximately 2 times higher than that for WS $\left(282 \mu \mathrm{gg}^{-1}\right.$, Table 3$)$. Based on two types of isotherms and pseudo-second-order kinetic modeling (also referred to as Ho model [13]) analyses, shells of BTS are the more suitable sorbents than those of WS for As removal from aqueous solution. In the previous study [13], Ho model was considered

Table 3

Pertinent parameters of pseudo-second-order sorption equation for black tiger shrimp and white shrimp shells.

\begin{tabular}{|c|c|c|c|c|c|c|}
\hline$C_{\mathrm{w}}\left(\mathrm{mg} \mathrm{L}^{-1}\right)$ & Slope $\left(g \mu g^{-1}\right)$ & Interception (hg $\left.\mu \mathrm{g}^{-1}\right)$ & $r^{2}$ & $q_{e}\left(\mu g g^{-1}\right)$ & $k\left(g \mu g^{-1} h^{-1}\right)$ & $h_{0}\left(k q_{e}^{2}\right)\left(\mu g g^{-1} \mathrm{~h}^{-1}\right)$ \\
\hline \multicolumn{7}{|c|}{ Black tiger shrimp } \\
\hline 0 & $3.85 \times 10^{0}$ & $9.70 \times 10^{-1}$ & 0.988 & $2.60 \times 10^{-1}$ & $1.52 \times 10^{-1}$ & $1.03 \times 10^{0}$ \\
\hline 1 & $1.01 \times 10^{-1}$ & $6.11 \times 10^{0}$ & 0.875 & $9.93 \times 10^{0}$ & $1.66 \times 10^{-3}$ & $1.64 \times 10^{-1}$ \\
\hline 2 & $1.06 \times 10^{-1}$ & $6.96 \times 10^{0}$ & 0.871 & $9.46 \times 10^{0}$ & $1.61 \times 10^{-3}$ & $1.44 \times 10^{-1}$ \\
\hline 5 & $4.88 \times 10^{-2}$ & $2.64 \times 10^{0}$ & 0.927 & $2.05 \times 10^{1}$ & $9.00 \times 10^{-4}$ & $3.78 \times 10^{-1}$ \\
\hline 10 & $1.73 \times 10^{-2}$ & $8.59 \times 10^{-1}$ & 0.935 & $5.79 \times 10^{1}$ & $3.48 \times 10^{-4}$ & $1.16 \times 10^{0}$ \\
\hline 20 & $1.28 \times 10^{-2}$ & $5.56 \times 10^{-2}$ & 0.999 & $7.83 \times 10^{1}$ & $2.93 \times 10^{-3}$ & $1.80 \times 10^{1}$ \\
\hline 40 & $8.32 \times 10^{-3}$ & $2.33 \times 10^{-2}$ & 0.999 & $1.20 \times 10^{2}$ & $2.97 \times 10^{-3}$ & $4.29 \times 10^{1}$ \\
\hline 60 & $2.49 \times 10^{-3}$ & $3.17 \times 10^{-3}$ & 0.998 & $4.02 \times 10^{2}$ & $1.95 \times 10^{-4}$ & $3.16 \times 10^{2}$ \\
\hline 80 & $1.89 \times 10^{-3}$ & $1.00 \times 10^{-2}$ & 0.967 & $5.30 \times 10^{2}$ & $3.55 \times 10^{-4}$ & $9.98 \times 10^{1}$ \\
\hline 100 & $1.76 \times 10^{-3}$ & $4.99 \times 10^{-3}$ & 0.972 & $5.69 \times 10^{2}$ & $6.19 \times 10^{-4}$ & $2.00 \times 10^{2}$ \\
\hline \multicolumn{7}{|c|}{ White shrimp } \\
\hline 0 & $4.90 \times 10^{0}$ & $7.49 \times 10^{0}$ & 0.984 & $2.04 \times 10^{-1}$ & $3.20 \times 10^{0}$ & $1.34 \times 10^{-1}$ \\
\hline 1 & $1.15 \times 10^{-1}$ & $5.57 \times 10^{0}$ & 0.932 & $8.68 \times 10^{0}$ & $2.38 \times 10^{-3}$ & $1.80 \times 10^{-1}$ \\
\hline 2 & $7.25 \times 10^{-2}$ & $2.06 \times 10^{0}$ & 0.985 & $1.38 \times 10^{1}$ & $2.56 \times 10^{-3}$ & $4.87 \times 10^{-1}$ \\
\hline 5 & $4.58 \times 10^{-2}$ & $2.37 \times 10^{0}$ & 0.954 & $2.18 \times 10^{1}$ & $8.86 \times 10^{-4}$ & $4.22 \times 10^{-1}$ \\
\hline 10 & $1.95 \times 10^{-2}$ & $4.35 \times 10^{-1}$ & 0.978 & $5.12 \times 10^{1}$ & $8.78 \times 10^{-4}$ & $2.30 \times 10^{0}$ \\
\hline 20 & $1.31 \times 10^{-2}$ & $4.68 \times 10^{-2}$ & 0.997 & $7.66 \times 10^{1}$ & $3.64 \times 10^{-3}$ & $2.14 \times 10^{1}$ \\
\hline 40 & $9.24 \times 10^{-3}$ & $2.80 \times 10^{-2}$ & 0.999 & $1.08 \times 10^{2}$ & $3.04 \times 10^{-3}$ & $3.57 \times 10^{1}$ \\
\hline 60 & $5.91 \times 10^{-3}$ & $1.51 \times 10^{-2}$ & 0.997 & $1.69 \times 10^{2}$ & $2.31 \times 10^{-3}$ & $6.62 \times 10^{1}$ \\
\hline 80 & $5.13 \times 10^{-3}$ & $6.27 \times 10^{-3}$ & 0.996 & $1.95 \times 10^{2}$ & $4.20 \times 10^{-3}$ & $1.59 \times 10^{2}$ \\
\hline 100 & $3.55 \times 10^{-3}$ & $1.41 \times 10^{-2}$ & 0.997 & $2.82 \times 10^{2}$ & $8.96 \times 10^{-4}$ & $7.11 \times 10^{1}$ \\
\hline
\end{tabular}


to be the best fit model for both of $\mathrm{As}(\mathrm{III})$ and $\mathrm{As}(\mathrm{V})$ contaminated solution at $\mathrm{pH}$ 6.0, whereas the Ho model also fitted well while the $\mathrm{pH}$ value was maintained between 6.03 and 7.02 in our study.

\section{Conclusions}

In the present study, it has been shown that the use of lowcost farmed shrimp shell for As removal appeared to be feasible technically. With a capacity of removing As from aqueous solution, shrimp shell may perform potentially to remove As from wastewater or As-contaminated groundwater. Shrimp shell, as a natural material, is available ideally with a low cost and is also environmental friendly. Besides that, being composed entirely of aquacultural and fishing industrial waste, it helps to reduce waste. Shrimp shells can easily be obtained, employed, and disposed of with low cost. They would be good candidates for adsorption of As in wastewater streams. The use of shrimp shell as sorbent should be investigated as a replacement for the current expensive methods to remove heavy metals from solution. The mechanism of As adsorption in shrimp shell should be revealed. To make the As removal more efficient, the use of a significant amount of shrimp shell is required, which implies that more research should be done on the desorption of As from the shells. Furthermore, studies concerning As as well as the other metals adsorbed by shrimp shells needed to be undertaken to provide more available information on shrimp shells as low-cost sorbents.

\section{Acknowledgment}

This work was financially supported by the National Science Council of Republic of China (NSC 93-2313-B-343-001).

\section{References}

[1] World Health Organization (WHO), Arsenic in drinking water, WHO Media Centre, World Health Organization, Geneva, Switzerland, available from the website (http://www.who.int/mediacentre/factsheets/fs210/en/index.html), 2009.

[2] J.C. Ng, J.P. Wang, A. Shraim, A global health problem caused by arsenic from natural sources, Chemosphere 52 (2003) 1353-1359.

[3] M.M. Wu, T.L. Kuo, Y.H. Hwang, C.J. Chen, Dose-response relation between As concentration in well water and mortality from cancers and vascular disease, Am. J. Epidemiol. 130 (1989) 1123-1131.

[4] M.C. Lin, C.M. Liao, C.W. Liu, S. Singh, Bioaccumulation of arsenic in aquacultural large-scale mullet Liza macrolepis from the blackfoot disease area in Taiwan, Bull. Environ. Contam. Toxicol. 67 (2001) 91-97.

[5] M.C. Lin, H.H. Cheng, H.Y. Lin, Y.C. Chen, Y.P. Chen, C.M. Liao, G.P. Chang-Chien, C.F. Dai, B.C. Han, C.W. Liu, Arsenic accumulation and acute toxicity in milkfish (Chanos chanos) from blackfoot disease area in Taiwan, Bull. Environ. Contam. Toxicol. 72 (2004) 248-254.

[6] M.C. Lin, H.Y. Lin, H.H. Cheng, Y.C. Chen, C.M. Liao, K.T. Shao, Risk assessment of arsenic exposure from consumption of cultured milkfish, Chanos chanos (Forsskål), from the arsenic-contaminated area in southwestern Taiwan, Bull. Environ. Contam. Toxicol. 75 (2005) 637-644.

[7] ATSDR (Agency for Toxic Substances Disease Registry), Toxicological Profile for Arsenic, Agency for Toxic Substances and Disease Registry, U.S. Department of Health and Human Services, Public Health Service, Washington, DC, 2000.
[8] C.O. Abernathy, D.J. Thomas, R.L. Calderon, Health effects and risk assessment of arsenic, J. Nutr. 133 (2003) 1536S-1538S.

[9] E.O. Kartinen, C.J. Martin, An overview of arsenic removal processes, Desalination 103 (1995) 79-88.

[10] M.N. Haque, G.M. Morrison, G. Perrusquía, M. Gutierréz, A.F. Aguilera, I. Cano-Aguilera, J.L. Gardea-Torresdey, Characteristics of arsenic adsorption to sorghum biomass, J. Hazard. Mater. 145 (2007) 30-35.

[11] D. Mohan, C.U. Pittman Jr., Arsenic removal from water/wastewater using adsorbents-a critical review, J. Hazard. Mater. 142 (2007) 1-53.

[12] Y.N. Chen, L.Y. Chai, Y.D. Shu, Study of arsenic (V) adsorption on bone char from aqueous solution, J. Hazard. Mater. 160 (2008) 168-172.

[13] S. Pokhrel, T. Viraraghavan, Arsenic removal from an aqueous solution by modified A. niger biomass: batch kinetic and isotherm studies, J. Hazard. Mater. 150 (2008) 818-825.

[14] A. Sarı, M. Tuzen, Biosorption of As(III), As(V) from aqueous solution by macrofungus (Inonotus hispidus) biomass: equilibrium and kinetic studies, J. Hazard. Mater. (2008), doi:10.1016/j.jhazmat.2008.09.047.

[15] S. Chakravarty, V. Dureja, G. Bhattacharyya, S. Maity, S. Bhattacharjee, Remova of arsenic from groundwater using low cost ferruginous manganese ore, Water Res. 36 (2002) 625-632.

[16] J.R. Deans, B.G. Dixon, Uptake of $\mathrm{Pb}^{2+}$ and $\mathrm{Cu}^{2+}$ by novel biopolymers, Water Res. 26 (1992) 469-472.

[17] F. Veglio, F. Beolchini, Removal of heavy metals by biosorption: a review Hydrometallurgy 44 (1997) 301-316.

[18] M.P. Elizalde-González, J. Mattusch, W.D. Einicke, R. Wennrich, Sorption on natural solids for arsenic removal, Chem. Eng. J. 81 (2003) 187-195.

[19] I.A. Katsoyiannis, A.I. Zouboulis, Application of biological processes for the removal of arsenic from groundwaters, Water Res. 38 (2004) 17-26.

[20] C.L. Chuang, M. Fan, M. Xu, R.C. Brown, S. Sung, B. Saha, C.P. Huang, Adsorption of arsenic $(\mathrm{V})$ by activated carbon prepared from oat hulls, Chemosphere 61 (2005) 478-483.

[21] S.E. Bailey, T.J. Olin, R.M. Bricka, D.D. Adrian, A review of potentially low costs sorbents for heavy metals, Water Res. 33 (1999) 2469-2479.

[22] M.V. Deshpande, Enzymatic degradation of chitin and its biological applications, J. Sci. Ind. Res. 45 (1986) 277-281.

[23] A.V. Ilyina, V.E. Tikhonov, V.P. Varlamov, L.A. Radigina, N.Y. Tatarinova, I.A. Yamskov, Preparation of affinity sorbents and isolation of individual chitinases from a crude supernatant produced by Streptomyces kurssanovii by a one-step affinity chromatographic system, Biotechnol. Appl. Biochem. 21 (1995) 139-148.

[24] H.K. An, B.Y. Park, D.S. Kim, Crab shell for the removal of heavy metals from aqueous solution, Water Res. 35 (2001) 3551-3556.

[25] J.M. Modak, K.A. Natarajan, Biosorption of metals using nonliving biomass: a review, Miner. Metall. Proc. 12 (1995) 189-196.

[26] A.M.J. Rubio, Sulphate and molybdate ions uptake by chitin-beads shrimp shells, Miner. Eng. 16 (2003) 715-722.

[27] M.C. Lin, C.M. Liao, Y.C. Chen, Shrimp shell as a potential sorbent for removal of arsenic from aqueous solution, Fish. Sci. 75 (2009) 425-434

[28] R.S. Juang, F.C. Wu, R.L. Tseng, Solute adsorption and enzyme immobilization on chitosan beads prepared from shrimp shell wastes, Bioresour. Technol. 80 (2001) 187-193.

[29] T. Fan, Y. Liu, B. Feng, G. Zeng, C. Yang, M. Zhou, H. Zhou, Z. Tan, X. Wang Biosorption of cadmium (II), zinc (II) and lead (II) by Penicillium simplicssimum: isotherms, kinetics and thermodynamics, J. Hazard. Mater. 160 (2008) 655-661.

[30] Y.S. Ho, G. McKay, The kinetics of sorption of divalent metal ions onto sphagnum moss peat, Water Res. 34 (2000) 735-742.

[31] U. Kumar, M. Bandyopadhyay, Sorption of cadmium from aqueous solution using pretreated rice husk, Bioresour. Technol. 97 (2006) 104-109.

[32] L. Dambies, T. Vincent, E. Guiba, Treatment of arsenic-containing solutions using chitosan derivatives: uptake mechanism and sorption performances, Water Res. 36 (2002) 3699-3710.

[33] N.K. Ghimire, K. Inoue, H. Yamaguchi, K. Makino, T. Miyajima, Adsorptive separation of arsenate and arsenite anions from aqueous medium by using orange waste, Water Res. 37 (2003) 4945-4953.

[34] T.C. Yang, R.R. Zall, Adsorption of metals by natural polymers generated from sea food processing wastes, Ind. Eng. Chem. Prod. Res. Dev. 23 (1984) 168172. 